\title{
Improving the laboratory diagnosis of leptospiral uveitis in horses by using an indirect ELISA for the detection of antibodies against Leptospira spp. in intraocular samples
}

\author{
Julia Loibl, Hartmut Gerhards, Siegfried Brem and Bettina Wollanke \\ Klinik für Pferde der LMU, Lehrstuhl für Innere Medizin und Chirurgie des Pferdes sowie für gerichtliche Tiermedizin
}

\begin{abstract}
Summary: Equine recurrent uveitis (ERU) is a frequently occurring disease, at least in horses in Germany. A vitrectomy is predominantly the course of action in cases where a chronic intraocular leptospiral infection is present. In some cases, the clinical and ophthalmological diagnosis is not conclusive and in these cases a preoperative laboratory test using anterior chamber fluid is indicated. However, false negative results occur when only MAT is used. The aim of this study was to investigate intraocular samples from horses with recurrent uveitis by using ELISA to detect anti-leptospiral antibodies and to compare the results to those of more established laboratory tests, i. e. MAT and PCR. Preliminary investigations indicated a high sensitivity of ELISA in the detection of leptospiral uveitis in horses. 80 eyes of 72 diseased horses were included in the study. The patients' history was taken and a thorough ophthalmologic examination was performed. Intraocular fluids were obtained by diagnostic anterior chamber paracentesis $(n=29)$ or therapeutic vitrectomy $(n=80)$ and submitted for MAT, ELISA and PCR to detect leptospiral antibodies and/or DNA. The ELISA allowed the separate determination of the immunoglobulin classes M, G and A. For statistical evaluation Cohen's kappa and the chi-square tests were applied and a p-value of 0.05 or less was considered to be significant. 22 healthy horses ( $n=42$ eyes) served as controls. $78 \%$ of vitreous samples from horses with ERU and $10 \%$ of healthy controls reacted positively in the MAT, whereas in the ELISA it was $85 \%$ and $0 \%$, and in the PCR it was $61 \%$ and $0 \%$, respectively. Specific IgA was detected in $84 \%$ of the vitreous samples from horses with ERU, and in $11 \%$ of cases, IgA was solely detectable. Differences were highly significant $(p<0.001)$. None of the aqueous samples in the control group contained leptospiral antibodies. Up to $64 \%$ of aqueous humour specimens that were obtained for diagnostic purposes yielded a positive result in the MAT. For the ELISA, it was even $89 \%$. Anti-leptospiral IgA was the most frequently detected immunoglobulin class. There was a high level of agreement in the MAT and ELISA results. However, ELISA provided a greater number of positive results. The detection of lgA against leptospires proved to be especially sensitive for an intraocular leptospiral infection and, thus, important for the laboratory diagnosis of leptospiral uveitis in horses. Looking at the cost involved in laboratory tests, it would be reasonable to start with an IgA ELISA. Only if there are negative results, additional tests could be performed. In single IgA negative cases there might be positive reactions using MAT, PCR or ELISA for $\lg G$ or $\lg$.
\end{abstract}

Keywords: horse, ophthalmology, uveitis, diagnostics, ELISA, leptospires, ERU

Citation: Loibl J., Gerhards H., Brem S., Wollanke B. (2018) Improving the laboratory diagnosis of leptospiral uveitis in horses by using an indirect ELISA for the detection of antibodies against Leptospira spp. in intraocular samples. Pferdeheilkunde 34, 267-277; DOI $10.21836 /$ PEM20180308

Correspondence: PD Dr. Bettina Wollanke, Universität München, Klinik für Pferde, Veterinärstraße 13, 50597 München, Germany; wollanke@lmu.de

\section{Introduction}

With a prevalence of $8 \%$ (Szemes and Gerhards 2000) equine recurrent uveitis (ERU) is the most frequently occurring ocular disease in horses worldwide. Moreover, it is the main reason for visual impairment and loss of vision in horses ( $\mathrm{Ka}$ sow and Dwyer 1997, Gerhards and Wollanke 2001, Sandmeyer et al. 2017). Thus, together with the laborious and costly treatment of the disease as well as its possibly negative impact on the horses' performance, ERU constitutes a great economic problem for horse owners and the equine industry. Furthermore, medical treatment that is essential during acute uveitic attacks, includes substances which are listed as prohibited by the FEl (Fédération Equestre Internationale) and other sport horse federations, meaning that these horses cannot take part in competitions.

ERU is characterized by acute, recurring, and painful inflammatory episodes alternating with quiescent stages of variable duration (Morter et al. 1969). The intraocular fluids of affected horses can be easily obtained from a therapeutic vitrectomy (Gerhards et al. 1999) or an anterior chamber paracen- tesis, and are therefore available for further analysis (Wollanke 2002, Gesell et al. 2006). These analyses have made a valuable contribution to the understanding and diagnosis of ERU. $90 \%$ of the vitreous samples from horses with ERU contained antibodies against leptospires in the microscopic agglutination test (MAT). Leptospiral DNA was detected in a polymerase chain reaction (PCR) in $70 \%$ of the specimens, and culture was successful in $50 \%$ of cases (Wollanke et al. 2004 a). Consequently, ERU can primarily be considered as a consequence of a chronic intraocular leptospiral infection. Moreover, autoimmune reactions can also be observed (Gilger et al. 1999).

Studies on autoimmune reactions, carried out by the research group of Deeg (Deeg et al. 2001, Deeg et al. 2002, Deeg et al. 2004, Deeg et al. 2006, Deeg 2008), were performed on identical intraocular samples from the same equine eyes used for the detection of an intraocular leptospiral infection mentioned above (Wollanke et al. 1998a,b, Brem et al. 1999a, Wollanke et al. 1999, Wollanke et al. 2000b, Gerhards and Wollanke 2001, Wollanke et al. 2001 a,b, Wollanke 2002, Hartskeerl et al. 2004, Wollanke et al. 2004 a, Niedermaier et al. 
2006, Brandes et al. 2007, Roczek 2008, Loib/2009, Wiehen 2012, Popp et al. 2013, Roth et al. 2014, Schinag/2017).

Recurrences of equine uveitis can only be observed during a persistent leptospiral infection. A vitrectomy, however, removes not only the vitreous cloudiness that is caused by the intraocular inflammation and impairs vision, but also the leptospiral infection itself (Wollanke et al. 2004a) and, therefore, successfully prevents further inflammatory episodes (Winterberg and Gerhards 1997, Wollanke 2002, Wollanke et al. 2004a, Gerhards and Wollanke 2005, von Borstel et al. 2005, Gerhards and Wollanke 2006, Tömördy et al. 2010, Schinag/ 2017). Consequently, in addition to the removal of vitreous opacities, the presence of an intraocular leptospiral infection is the primary indication for a therapeutic vitrectomy in affected horses (Gerhards et al. 1999, Wollanke 2002, Wollanke et al. 2004a, Gerhards und Wollanke 2005, von Borstel et al. 2005, Gerhards und Wollanke 2006, Tömördy et al. 2010, von Borstel et al. 2010, Schinagl 2017).

In most cases, a careful ophthalmological examination can differentiate between leptospiral uveitis and other forms of uveitis, e.g. phacogenic uveitis, traumatic uveitis, septic uveitis, leopard coat pattern uveitis or a chronic iritis (Wollanke 2002, Wollanke et al. 2004a, Gerhards and Wollanke 2006). However, in some cases the ophthalmological findings are questionable (either no abnormal findings during quiet intervals or cases of possible phacogenic or leopard coat pattern uveitis). In these cases, the indication for surgery can be verified by sampling anterior chamber fluid and testing for leptospiral antibodies and leptospiral DNA prior to the vitrectomy (Gerhards et al. 1999, Wollanke 2002, Wollanke et al. 2004a, Gerhards and Wollanke 2005, Gerhards and Wollanke 2006, Tömördy et al. 2010, Schinag/ 2017).

As has been shown in earlier investigations, there is an intraocular antibody production in ERU (Wollanke 2002, Wollanke et al. 2004 a). MAT results with paired samples (serum and intraocular fluid) from the same horses showed that they were independent. Intraocular titres are usually much higher than serum titres and intraocular fluids and serum from the same horse often react with different serovars, meaning that the titres in intraocular fluids cannot result from serum leakage.

Intraocular titres are usually much higher than serum titres and are often directed against different serovars (Wollanke et al. 1998a, Wollanke et al. 2001b, Wollanke et al. 2004a). There is hardly any albumine in inflamed eyes, which would be expected from the serum leakage, because albumines are smaller than globulines (Wollanke 2005). Furthermore, antibodies against leptospires were found in the intraocular fluids, but none were found against other infectious agents such as Borrelia, Toxoplasma and Herpes virus, which were detectable in the serum of the horses (Wollanke 1995, Wollanke et al. 1998a,b,c, Wollanke et al. 2004a, Wollanke et al. $2017 a)$. Finally, in horses with intraocular bleeding there are no antibodies detectable within a very short amount of time in the intraocular fluids. In eyes suffering from glaucoma and a severe breakdown of the blood-ocular barrier, there are no antibodies detectable in the intraocular fluids either (Wollanke 2002, Wollanke et al. 2004 a). Thus, leptospiral antibodies in intraocular fluids are not a consequence of the bloodocular barrier breaking down and leakage of serum proteins into the eye during acute attacks, but rather proof of an intraocular leptospiral infection.

Only a few reports on the application of an enzyme-linked immunosorbent assay (ELISA) for the intraocular detection of specific, anti-leptospiral antibodies in horses with ERU have been published to date (Halliwell et al. 1985, Parma et al. 1987, Brem et al. 1999a, Verma et al. 2005, Loib/ 2009). Preliminary investigations, however, foreshadowed that the ELISA-technique, and especially the intraocular detection of $\lg A$ against leptospires, was very sensitive for the diagnosis of leptospiral uveitis in horses (Brem et al. 2005).

The primary purpose of this study was to investigate intraocular specimens (vitreous and aqueous humour) of horses with ERU using an indirect ELISA-technique to detect specific, antileptospiral immunoglobulins $M, G$ and A. A further aim of the study was to analyse and evaluate the suitability of the ELISA for the detection of an intraocular leptospiral infection and to compare its results to those of more established laboratory tests, i.e. MAT and PCR. An optimization of the approach to laboratory diagnosis in the context of diagnostic paracenteses in horses without a definite clinical diagnosis in terms of ERU was hence an integral part of the study.

\section{Materials and methods}

Horses

72 diseased horses were included in the study. The patient population comprised cases that were presented or referred to the equine clinic of the Ludwig-Maximilians-University (LMU) Munich, Germany, for vitrectomy either following a clinical diagnosis of recurrent uveitis or a positive test result regarding leptospiral antibodies and/or DNA in an aqueous humour analysis. 22 horses without ocular complaints that had to be euthanized for ethical reasons served as controls. The age of the horses with ERU ranged between 2 and 15 years (average 7.8 years). The control horses were between 2 and 32 years old (average 13.0 years). 23 mares (control group: 9), 43 geldings (control group: 11) and 6 stallions (control group: 2) of different colour and breed were represented. The horses mainly came from Germany, although some came from Austria, Switzerland and the Czech Republic.

\section{History}

The history of the patient group focused on the total duration of the disease, the number of uveitic attacks observed and the period of time that had passed since the last inflammatory episode. For the control horses a prior ocular disease or irritation was anamnestically excluded as far as was possible.

\section{Ophthalmologic examination}

Every horse was subjected to a complete ophthalmoloical examination. This examination particularly focused on the unambiguity of clinical signs in terms of ERU, the severity of ocular changes as well as the manifestation of the disease predominantly as anterior uveitis, posterior uveitis or panuveitis. In the control 
Table 1 Overview of intraocular specimens analysed in the course of the study. | Übersicht über die intraokularen Proben, die in der vorliegenden Studie untersucht wurden.

\begin{tabular}{|c|c|c|c|c|}
\hline Type of sample & Total & Number of samples in groups & Groups & Abbreviations \\
\hline \multirow[t]{2}{*}{ Vitreous material } & 122 & 80 & ERU & VMI \\
\hline & & 42 & Healthy controls & VMO \\
\hline \multirow[t]{4}{*}{ Aqueous humour } & 71 & 16 & Healthy eye of horses with unilateral ERU & $\mathrm{AHla}$ \\
\hline & & 2 & ERU & $\mathrm{AHIb}$ \\
\hline & & 11 & ERU in question & $\mathrm{AH} 1 \mathrm{c}$ \\
\hline & & 42 & Healthy controls & $\mathrm{AHO}$ \\
\hline
\end{tabular}

group a careful ophthalmic examination was performed while the horse was alive, if possible, otherwise straight after euthanasia. Therein, any ocular changes that are known to be symptoms of ERU led to an exclusion of the horse from the study.

\section{Intraocular specimens}

122 vitreous specimens were analysed in the course of this study (Table 1). Thereof, 80 vitreous samples were obtained during therapeutic vitrectomies (VM1). These surgeries were performed as described by Gerhards et al. (1999). A threeway port attached to the vitrectomy instrument allowed the sterile withdrawal of $3-5 \mathrm{ml}$ undiluted vitreous material with a $5 \mathrm{ml}$-syringe at the beginning of the surgery before the dripping line for the lavage fluid was opened. 42 vitreous specimens of healthy controls were obtained directly after euthanasia using a sterile intravenous catheter (VMO).

Furthermore, 71 aqueous specimens were analysed (Table 1). Thereof, 42 belonged to healthy horses in the control group (AHO). In 16 cases an aqueous sample was withdrawn from the clinically healthy eye of horses that underwent a vitrectomy $(\mathrm{AHla})$. This was done at the request of the horses' owners, in order to rule out a potentially unapparent intraocular infection of the other eye.

Two samples were obtained during synechiolysis which was necessary before a vitrectomy could be performed ( $\mathrm{AH} 1 \mathrm{~b})$. Another 11 horses lacking unambiguous clinical signs of recurrent uveitis underwent an anterior chamber paracentesis to indicate whether a vitrectomy was to be carried out (AH1 c). (Note: Far more horses were subjected to a diagnostic anterior chamber paracentesis during the study, but only cases with a laboratory diagnosis of leptospiral uveitis that subsequently underwent a vitrectomy were included in the study). In horses with ocular complaints, $0.5-1.0 \mathrm{ml}$ of aqueous humour was extracted by limbal paracentesis with a $2 \mathrm{ml}$ syringe and a $27 \mathrm{G}$ hypodermic needle under a short general anaesthesia. In the control horses the sample was obtained the same way immediately after euthanasia.

\section{Microbiological analyses}

Intraocular samples were submitted for the following laboratory tests: MAT and ELISA for the detection of leptospiral antibodies, and PCR for the detection of leptospiral DNA. The tests were conducted by the leptospirosis laboratory, which is part of the Bavarian Health and Food Safety Authority (LGL), in Oberschleißheim, Germany.
The microscopic agglutination test was performed in accordance with the guidelines of the O.I.E. (Office International des Epizooties, The World Organisation for Animal Health, OIE 2014). The following leptospiral serovars were used as live antigens: Bratislava, Canicola, Copenhageni, Grippotyphosa, Hardjo, Icterohaemorrhagiae, Javanica, Pomona, Pyrogenes, Saxkoebing, Sejroe and Tarassovi. Titres higher than 1:100 were assessed as being specific. The highest titre measured was included in the results. To simplify the statistical evaluation, the respective serovar was not taken into account any further.

The in-house ELISA-technique initially assumed an antigen extraction and was developed by Kettner (1997). This indirect technique, which utilized a complete leptospiral antigen, allowed both the qualitative and quantitative determination of the immune response as single immunoglobulin classes, i.e. IgM, $\lg G$ and $\lg A$, were detected separately using anti-horse $\lg A$, anti-horse $\lg G$ and anti-horse $\lg M$ and could reach different values. Thus, a sample could deliver a negative (-), borderline $(+/-)$, weakly positive $(+)$, positive $(++)$ or highly positive result $(+++)$ depending on its optical density, determined using photometry (wave length $405 \mathrm{~nm}$ ) (Table 2). For statistical evaluation a borderline result was assessed as being negative.

The serovars for the ELISA were chosen according to the positive results in the MAT and the geographical origin of the horse. Each specimen was analysed applying between one and four different serovars. In the case of a negative test result in the MAT, the ELISA was conducted with a Grippotyphosa and a Bratislava antigen. The following serovars were used: Bratislava, Canicola, Copenhageni, Grippotyphosa, Icterohaemorrhagiae and Pomona. To simplify the statistical evaluation and the comparison of results from different horses, the ELISA results for the respective leptospiral serovars were not differentiated. Only the highest extinction measured for each immunoglobulin class accounted for the evaluation.

\begin{tabular}{lccccc}
\hline $\begin{array}{l}\text { Table } 4 \\
\text { leptospiral antibodies and DNA in aqueous and vitreous specimens }\end{array}$ \\
of the same eye in horses with recurrent uveitis. / Übereinstimmung \\
derErgebnisse von Kammerwasser- und Glaskörperproben \\
aus denselben Augen bei Verwendung von MAR, ELISA und PCR. \\
\hline Laboratory test & Total & $\mathrm{N}_{\mathrm{AH}+\mathrm{VM}+}$ & $\mathrm{N}_{\mathrm{AH}-\mathrm{VM}+}$ & $\mathrm{N}_{\mathrm{AH}+\mathrm{VM}-}$ & $\mathrm{N}_{\mathrm{AH}-\mathrm{VM}-}$ \\
\hline MAT & 14 & 8 & 4 & 2 & 0 \\
ELISA & 12 & 8 & 2 & 2 & 0 \\
PCR & 11 & 0 & 4 & 6 & 1 \\
\hline
\end{tabular}


79 vitreous samples from horses with ERU, the 42 vitreous specimens of the control group and all aqueous samples were analysed by quantitative real time PCR targeting the lipL32 gene present only in pathogenic Leptospira spp. This technique was established by Roczek and others (2008).

\section{Statistics}

For statistical evaluation Cohen's kappa and the chi-square tests were applied (SPSS for Windows version 16.0). A pvalue of 0.05 or less was considered significant.

\section{Results}

Ophthalmologic examination:

In 66 (82.5\%) out of 80 equine eyes in the patient group typical ocular findings in terms of ERU allowed a definite clinical diagnosis. In 14 cases (17.5\%) the findings were uncertain in terms of ERU, but an intraocular leptospiral infection was confirmed by aqueous humour analysis prior to surgery.

\section{Laboratory findings:}

$78 \%(62 / 80)$ of the vitreous samples from horses with ERU (VM1) - but only 10\% (4/42) of those in the control group (VMO) - contained leptospiral antibodies that were detectable by MAT. The difference was highly significant (Fisher's Exact Test, $p<0.001$ ) (Table 3). The titre found most often among horses with ERU was 1:800. The median was 1:400 and the highest titre was $1: 102,400$. The four positive specimens in the control group all yielded a titre of 1:100 and belonged to three different horses. Anti-leptospiral antibodies were detected in $85 \%(68 / 80)$ of the vitreous samples from horses with ERU (VM1) using ELISA, but none were detected in the control group (VMO) (Table 3). The difference, again, was highly significant (Fisher's Exact Test, $p<0.001$ ).

IgM antibodies against leptospires were detected in 34\% $(27 / 80)$ of the vitreous samples from horses with ERU. For $\lg G$ it was $74 \%(59 / 80)$ and for $\lg A$ it was $84 \%$ (67/80). In $11 \%$ of the cases, the detection of $\lg A$ - compared to $\lg M$ or $\lg G$ - was most frequently solely successful (9/80). IgG was once solely detected. $39 \%(31 / 80)$ of the vitreous specimens contained detectable immunoglobulins of both classes, $G$ and $A$, and $34 \%(27 / 80)$ had all three classes. Leptospiral DNA was detected in $61 \%(48 / 79)$ of the vitreous samples obtained from horses with recurrent uveitis (VM1), whereas

Table 3 Differences between horses with ERU and controls concerning positive test results as to leptospiral antibodies or DNA in vitreous material. | Vorkommen von Antikörpern gegen Leptospiren und Nachweis von Leptospiren-DNA in Glaskörperproben

\begin{tabular}{lccl}
\hline Laboratory test & \multicolumn{1}{l}{ ERU } & Control & p-value \\
\cline { 2 - 3 } & \multicolumn{2}{l}{ Percentage of positive results } & \\
\cline { 2 - 3 } MAT & $78 \%$ & $10 \%$ & $\mathrm{p}<0.001$ \\
ELISA & $85 \%$ & $0 \%$ & $\mathrm{p}<0.001$ \\
PCR & $61 \%$ & $0 \%$ & $\mathrm{p}<0.001$ \\
\hline
\end{tabular}

none of the specimens in the control group (VMO) showed a positive reaction (Table 3 ). The difference was highly significant (Fisher's Exact Test, $\mathrm{p}<0.001$ ).

None of the aqueous samples in the control group ( $\mathrm{AHO}$ ) contained leptospiral antibodies when tested with MAT or ELISA (Table 4). 3 out of 16 (19\%) specimens that had been taken from horses' clinically healthy eyes during general anaesthesia for vitrectomy on the respectively other eye demonstrated a positive result in MAT as well as in ELISA (AHla).

Titres of 1:100, 1:200 and 1:400 were determined by MAT. Specific $\lg M$ was not detectable with ELISA whereas $\lg G$ against leptospires was detected twice, and $\lg A$ was detected three times, i.e. in all cases. All three horses underwent a vitrectomy on their owners' request within the following week. One of the two samples from horses with obvious clinical signs of recurrent uveitis (synechiolysis prior to surgery because of miotic pupils and impaired vision into the vitreous) reacted positively when both MAT and ELISA were applied (AH1 b). The titre was $1: 200$, and specific immunoglobulins of classes $G$ and $A$ were detectable in the same sample. The second sample, however, remained negative. $64 \%(7 / 11)$ of the aqueous samples from equine eyes without definite clinical signs in terms of ERU - but in the end at least one positive test result - contained leptospiral antibodies detectable by MAT (AH1c). When ELISA was applied, it was $89 \%$ (8/9). Titres up to $1: 1,600$ were determined by MAT.

ELISA delivered the following percentages of positive results considering the single immunoglobulin classes of anti-leptospiral antibodies: IgM 22\% (2/9), IgG 56\% (5/9) and $\lg A$ $89 \%(8 / 9)$. Thus, IgA was detected in every sample that was assessed as positive by ELISA. Differences between horses with ERU and those in the control group were highly significant with regards to MAT and ELISA results (Fisher's Exact Test, $\mathrm{p}<0.001)$.

Leptospiral DNA could not be detected by PCR in any of the aqueous samples of the control group (AHO). One specimen in the group of horses that suffered from unilateral recurrent

Table 4 Agreement of test results (MAT, ELISA and PCR) as to leptospiral antibodies and DNA in aqueous and vitreous specimens of the same eye in horses with recurrent uveitis. / Übereinstimmung derErgebnisse von Kammerwasser- und Glaskörperproben aus denselben Augen bei Verwendung von MAR, ELISA und PCR.

\begin{tabular}{lrrrcc}
\hline Laboratory test & Total & $\mathrm{N}_{\mathrm{AH}+\mathrm{VM}+}$ & $\mathrm{N}_{\mathrm{AH}-\mathrm{VM}+}$ & $\mathrm{N}_{\mathrm{AH}+\mathrm{VM}-}$ & $\mathrm{N}_{\mathrm{AH}-\mathrm{VM}-}$ \\
\hline MAT & 14 & 8 & 4 & 2 & 0 \\
ELISA & 12 & 8 & 2 & 2 & 0 \\
PCR & 11 & 0 & 4 & 6 & 1 \\
\hline
\end{tabular}

Table 5 Agreement of MAT and ELISA as to positive or negative test results in the detection of leptospiral antibodies in intraocular samples of horses with ERU. | Vergleich der Ergebnisse beiden Antikörpertests (MAR und ELISA) in intraokularen Proben von an ERU erkrankten Pferden.

\begin{tabular}{lrcccc}
\hline Specimen & Total & $\mathrm{n}_{\text {both }}$ & $\mathrm{n}_{\text {both- }}$ & $\mathrm{n}_{\text {MAT+ELSA- }}$ & $\mathrm{n}_{\text {MAT- }}$ \\
\hline Vitreous & 80 & 61 & 11 & 1 & 7 \\
Aqueous humour & 14 & 8 & 1 & 1 & 4 \\
\hline
\end{tabular}


uveitis and underwent paracentesis on the other eye reacted positively in PCR (AHla). The specimen belonged to one of the three horses whose aqueous samples also contained antibodies against Leptospira spp. PCR was applied in only one of the two cases with a definite clinical diagnosis of ERU $(\mathrm{AH} 1 \mathrm{~b})$. Thus, it delivered a positive test result. An investigation of the aqueous humour by PCR was initiated in 9 out of 11 cases without definite clinical signs of recurrent uveitis (AHlc). Therein, 5 (45\%) samples were assessed as positive. The difference regarding PCR results of horses with ERU and those in the control group was highly significant (Fisher's Exact Test, $\mathrm{p}<0.001$ ).

In the context of this study samples from both ocular compartments of the same equine eye, i.e. aqueous and vitreous fluids, were taken for further analysis and then compared to the laboratory results from 14 (MAT), 12 (ELISA), and 11 (PCR) eyes with recurrent uveitis. Table 5 gives an abridgement of the test results (MAT, ELISA and PCR) for both ocular compartments.

In eight cases specific antibodies were detectable in both samples by MAT (57\%). Four times the MAT result was negative for both compartments (29\%). Only twice did the aqueous humour contain detectable antibodies against leptospires (14\%), whereas the vitreous of the same eyes was MAT negative. Thus, the qualitative information of the MAT regarding the two ocular compartments agreed in $86 \%$ of the cases.

Eight paired samples contained anti-leptospiral antibodies that could be detected by ELISA (67\%). Two pairs agreed in their negative result (17\%). Specific antibodies were only detectable in the aqueous humour twice (17\%). The same combination of negative and positive test results for the distinct immunoglobulin classes could be observed for nine paired samples (75\%). Three pairs differed in their ELISA profile $(25 \%)$. In four cases aqueous and vitreous samples agreed in their negative PCR result (36\%). Leptospiral DNA was only detected in the aqueous humour six times (55\%) and only once in the vitreous specimen (9\%).

80 vitreous samples from horses with ERU were analysed for leptospiral antibodies using MAT and ELISA. Therein, 61 (76\%) showed a positive result in both tests. 11 (14\%) did not contain any detectable anti-leptospiral antibodies. Specific antibodies were solely detected by MAT once (1\%), and in seven cases ( $9 \%$ ) they were solely detected by ELISA (Table 5). A high level of agreement was observed between MAT and ELISA tests ( $=0.675 ; p<0.001)$. None of the seven vitreous samples that reacted positively when only ELISA was applied contained specific IgM antibodies. In four cases lgG (57\%) and in six cases $\lg A$ (86\%) antibodies against leptospires were detected. IgA was solely detectable three times, and $\lg G$ was solely detectable in one case.

14 aqueous samples from horses with ERU were analysed for leptospiral antibodies using MAT and ELISA. In eight cases (57\%) anti-leptospiral antibodies were detectable in both laboratory techniques. One specimen did not react positively in any of the two tests (7\%). Four times solely the ELISA result was positive (29\%). A further sample showed a positive result when only MAT was applied (7\%) (Table 6). There was no significant level of agreement calculated.

Only one of the four aqueous samples with anti-leptospiral antibodies solely detectable with ELISA contained specific antibodies of all three immunoglobulin classes tested (25\%). One contained $\lg G$ as well as $\lg A(25 \%)$ and two specimens contained solely IgA (50\%). Thus, IgA against leptospires was detectable in all samples with a negative test result in the MAT.

The sensitivity and specificity of the ELISA technique in analysing vitreous samples from horses with ERU (including those with a positive test result in the aqueous humour analysis for leptospiral DNA and/or antibodies beforehand) was calculated setting the MAT as the basing point, as is often described in literature (gold standard). The sensitivity was $98 \%$ and the specificity $61 \%$.

The diagnostic sensitivity and specificity of the MAT, ELISA and PCR based on definite ocular findings in terms of ERU were only calculated for cases without a laboratory confirmation of an intraocular leptospiral infection by aqueous humour analysis beforehand. Thus, the calculation was made for 66 (MAT and ELISA) and 65 (PCR) vitreous samples from horses with clinical ERU, respectively, and 42 specimens of control horses (Table 7).

\section{Discussion}

Although some authors have already used the MAT to investigate the local humoral immune response to leptospires in horses with ERU and others have concentrated on the analysis of the systemic antibody production of affected horses, information on the detection of intraocular antibodies against leptospires in horses with ERU using ELISA is very rare.

Table 6 Sensitivity, specificity, positive and negative predictive values for MAT, ELISA and PCR using vitreous samples from horses showing definite ocular findings in terms of ERU but without laboratory confirmation prior to vitrectomy. I Sensitivität, Spezifität, positiver und negativer prädiktiver Wert für MAR, ELISA und PCR bei Verwendung von Glaskörperproben von Pferden, bei denen präoperativ ausschließlich anhand klinisch-ophthalmologischer Untersuchung die Diagnose ERU gestellt wurde und präoperativ keine Labordiagnostik durchgeführt wurde.

\begin{tabular}{lcccc}
\hline Laboratory Test & Sensitivity & Specificity & Positive Predictive Value & Negative Predictive Value \\
\hline MAT & $82 \%$ & $91 \%$ & $93 \%$ & $76 \%$ \\
ELISA & $86 \%$ & $100 \%$ & $100 \%$ & $82 \%$ \\
PCR & $72 \%$ & $100 \%$ & $100 \%$ & $70 \%$ \\
IgM-ELISA & $39 \%$ & $100 \%$ & $100 \%$ & $51 \%$ \\
IgG-ELISA & $80 \%$ & $100 \%$ & $100 \%$ & $79 \%$ \\
IgA-ELISA & $86 \%$ & $100 \%$ & $100 \%$ & $82 \%$ \\
\hline
\end{tabular}


As described previously (Wollanke et al. 2004a, Loibl 2009), significant differences in the detection of intraocular antibodies against leptospires using MAT (as well as ELISA) were observed in horses with recurrent uveitis and healthy controls. The percentage of positive results in the MAT among clinically healthy horses regarding vitreous samples (10\%), however, was slightly higher than in other studies (0-6\%) (Wollanke et al. 1998a, Wollanke et al. 2001 a,b, Gesell 2004, Wollanke et al. 2004 a). Wollanke and others (2001b) hypothesized that in such cases, too, recurrent uveitis could develop eventually. However, a follow-up examination of the affected equine eyes was not possible as the samples had been taken after the control horses had been euthanised.

In the present study specific IgA was the immunoglobulin class most often intraocularly detected by ELISA (in aqueous as well as vitreous humour). Moreover, in some cases it was solely detectable. This suggests that the detection of $\lg \mathrm{A}$ against leptospires is in fact very sensitive for an intraocular leptospiral infection. According to the results of this study, a false positive result of the IgA ELISA seems very unlikely because in intraocular samples from the controls - unlike MAT - no anti-leptospiral antibodies were detectable with ELISA, and no bacterial DNA was detected with PCR. This argues for the reliability of the ELISA technique in the diagnosis of an intraocular leptospiral infection. The intraocular appearance of IgA can probably be attributed to local production and secretion, as $\lg G$ - which was detected more frequently in serum than IgA (Loib/2009) - despite its lower molecular weight (IgG $=180 \mathrm{kDa}$ compared to the dimeric $\lg A$ (150 kDa as monomer)) (Tizard 2004) was less frequently found in intraocular samples. Wagner and others (1997) also observed a selective and considerable relative increase of the IgA content in vitreous samples compared to the autogenic serum in horses with ERU. This observation was not made in healthy horses. The authors assumed an increased local synthesis as an expression of a local immune reaction to an intraocular antigen. Moreover, Verma and co-workers (2005) detected IgA antibodies against leptospiral lipoproteins, LruA and LruB, using ELISA solely in uveitic equine eyes. The results of our study together with those found in literature point to the crucial role of (specific) IgA in the pathogenesis of ERU and the value of an IgA ELISA for the diagnosis of an intraocular leptospiral infection in horses.

In $14 \%$ of the vitreous specimens of horses with suspected leptospiral uveitis by ophthalmological examination leptospiral antibodies could not be detected neither with MAT nor ELISA. This observation is consistent with studies of other authors who also failed to detect specific antibodies in all of the intraocular samples from horses suffering from recurrent uveitis (Wollanke et al. 1998a,b, Wollanke et al. 2001 a,b, Wollanke et al. 2004a, Brandes et al. 2007, Tömördy et al. 2010, Wiehen 2012, Kulbrock et al. 2013, Baake et al. 2016, Dorrego Keiter et al. 2016, Dorrego Keiter et al. 2017). The different percentages of Leptospira positive and negative samples might be attributable to different methods in case selection and sampling techniques.

Biofilm formation plays an important role in the survival of bacteria and evasion from the immune system and their protection from environmental threats, and has been described for apathogenic and pathogenic Leptospira spp. (Ristow et al.
2008, Brihuega et al. 2012, Kumar et al. 2015, Thibeaux et al. 2017). This phenomenon might contribute to false negative test results.

Furthermore, Wollanke and others (1998a) hypothesized that other pathogens besides Leptospira spp. and further factors could have an influence on the development of ERU, but until today no other infectious agents, e.g. herpes virus, Toxoplasma spp., or Borrelia spp., could be linked to ERU (Wollanke 1995, Wollanke et al. 1998b, Wollanke et al. 2000b). Only Micronema (= Halicephalobus) and Borrelia spp. seem to induce some kind of severe uveitis, but clinically different from the typical ERU (Rames et al. 1995, Burgess et al. 1986, Barnett et al. 1995, Hahn et al. 1996, Isaza et al. 2000, Kinde et al. 2000, Wollanke et al. 2000a, Boswinkel et al. 2006, Wagner et al. 201 1, Priest et al. 2012, Wollanke et al. 2017 a).

Finally, ERU could be a purely autoimmune-mediated process in some cases, an approach that is favoured by others (Deeg et al. 2001, Deeg et al. 2002, Deeg et al. 2004, Deeg et al. 2006, Deeg 2008, Gilger et al. 2008). At this point, however, it seems to be important to keep in mind that Deeg and coworkers performed their studies on vitreous material which had been tested positive for leptospiral infections in most cases, as mentioned in the introduction. Besides, other ocular samples used for investigations in autoimmune reactions have not been tested for a leptospiral infection. It is plausible that a persistent intraocular leptospiral infection is accompanied by certain autoimmune reactions (Wollanke 2002, Wollanke et al. 2004 a).

Regional differences might play a role in the prevalence of leptospiral uveitis because humidity and vectors (e.g. mice and rats) are important both for the survival of the bacteria in the environment and for the infection of horses (Faine et al. 2000, Wollanke et al. 2004 a,b). If leptospires are present in the surroundings of equids, most horses have detectable antibodies in the serum and some of them may develop uveitis (Wollanke et al. 1998a, Szemes and Gerhards 2000). There is not a single serovar which causes recurrent uveitis in horses. To the contrary, different serovars are able to infect the equine eyes and cause recurrent uveitis (Wollanke et al. 2001 b, Wollanke et al. 2004 a). Which particular serovar can be detected in the eyes depends on the region in which the horse grew up or lives, which vectors live there, and thus, which serovars are attendant. Leptospiral uveitis is a common problem not only in horses in central Europe, but in other countries and continents, too - though in different prevalence (Witmer 1954, Williams 1968, Morter et al. 1969, Bernard 1993, Faber et al. 2000). In leopard coat pattern horses, uveitis often is less painful, initially shows a cataract formation, tends to develop glaucoma in many cases, and is not a leptospiral uveitis (Baumgart and Gerhards 2014).

While not a single aqueous sample of the control horses without a history or clinical signs of recurrent uveitis reacted positively in neither MAT nor ELISA, 19\% of the aqueous specimens of the clinically healthy eye of horses with unilateral ERU, however, contained anti-leptospiral antibodies that were detectable in both MAT and ELISA. Consequently, a preventive screening of equine eyes without a history or symptoms of ocular disease does not seem advisable due to anaesthetic 
risks and the danger of an ocular infection following paracentesis. Performing an anterior chamber paracentesis in the clinically healthy eye of horses with unilateral recurrent uveitis, however, can be taken into consideration during general anaesthesia for a vitrectomy of the affected eye. Consequences of a positive test result regarding an intraocular leptospiral infection, i.e. performing a vitrectomy or awaiting definitive clinical symptoms, need to be carefully pondered.

Leptospiral DNA could be detected in 61\% of the vitreous samples from horses with ERU, whereas in the control group none showed a positive reaction. Other authors reported on $57 \%$ to $100 \%$ of positive test results in intraocular samples from horses with ERU (Faber et al. 2000, Wollanke 2002, Gesell 2004, Wollanke et al. 2004a, Brandes et al. 2007, Wiehen 2012, Baake et al. 2016, Dorrego Keiter et al. 2016, Schinag/ 2017). The frequent detection of leptospiral DNA in intraocular material of equine eyes with recurrent uveitis confirmed that leptospires play a decisive role in the aetiology and pathogenesis of the disease.

In this study, the detection of specific antibodies seemed more sensitive for an intraocular leptospiral infection than the application of PCR. No additional information was gained by the use of PCR when aqueous samples were investigated following diagnostic paracentesis. A different study based on a larger patient population, however, revealed that, especially in cases without a definite clinical diagnosis of ERU, PCR serves as a valuable supplementation to MAT or ELISA in the analysis of aqueous samples for determining the aetiology of ocular changes (Gesell et al. 2006). The different results of this study compared to others can possibly be ascribed to differences in the patient population, the smaller number of aqueous samples analysed or deviant criteria in the patient selection process. In both studies the PCR was carried out by the same laboratory. Therefore, different laboratory techniques do not account for the different results.

It is remarkable that the detection of leptospiral DNA in this study was nearly as successful in the aqueous humour (in total) as in the vitreous material of horses with (suspected) recurrent uveitis. This suggests that at the beginning of the disease, leptospires disperse more equally in the equine eye (and are therefore more easily detected in the aqueous humor). However, as the disease progresses, the leptospires persist mainly in the avascular vitreous body, having been eliminated from the uvea and the anterior chamber (Brandes et al. 2007).

In $90 \%$ of the vitreous and $64 \%$ of the aqueous specimens of horses with ERU, the test results of MAT and ELISA for leptospiral antibodies were consistent, i.e. in each case negative or positive. Otherwise, anti-leptospiral antibodies were mostly detected solely by ELISA.

The observation that none (vitreous), or only one (aqueous) of the samples, respectively, that showed a positive test result solely in the ELISA contained detectable IgM antibodies can presumably be ascribed to the fact that $\lg M$ is primarily responsible for agglutination and therefore, of all the immunoglobulin classes is best detected by MAT (Hanson 1973, Priya et al. 2003). The samples only reacted positively in the ELISA as they seemingly did not contain any detectable amounts of specific IgM. However, one needs to be aware that IgM against leptospires could be least frequently detected intraocularly in this study. Besides, it was noticeable that the majority of samples with a negative result in the MAT contained specific $\lg \mathrm{A}$, and some of them in turn contained solely $\lg \mathrm{A}$. This observation is consistent with the retrospective evaluation of ELISA results of intraocular samples from horses with ERU where anti-leptospiral IgA was the most frequently detected immunoglobulin class (99\%), and was solely detectable in $63 \%$ of specimens (Loib/2009). Thus, compared to the other two immunoglobulin classes tested, especially the detection of IgA by ELISA, it seems suitable to complement the MAT in the analysis of intraocular specimens for anti-leptospiral antibodies.

Although in this study aqueous and vitreous humour of the identical equine eye were obtained and analysed from only very few cases of recurrent uveitis, it seemed justified to compare the laboratory results of the two compartments as other studies had achieved similar results (Wollanke 2002, Gesell et al. 2005, Gesell et al. 2006). Furthermore, in this study, too, MAT and ELISA results largely agreed in the paired samples. There is no considerable barrier between the aqueous humour and the vitreous body meaning that there is a diffusion of soluble agents between the two compartments (Gum 1991).

Due to the aqueous humour dynamics, the distribution of antibodies within the eye is relatively equal. Thus, one can act on the assumption that findings in the aqueous chamber correlate well with the situation in the posterior eye segment (Thurau 2003). Therefore, the suitability of a diagnostic anterior chamber paracentesis to verify an indication for a vitrectomy in cases missing definite clinical signs in terms of ERU could be confirmed. Furthermore, unnecessary, invasive and expensive intraocular surgeries can be avoided.

This equine clinic has years of experience and knowledge in the examination of equine uveitic eyes and diagnosing recurrent uveitis based on clinical findings. Furthermore, studies have proved the high agreement of the clinical diagnosis "leptospiral uveitis" with a successful laboratory investigation of intraocular samples from the respective eye for leptospiral antibodies by MAT (Wollanke et al. 2004 a). Thus, it seemed justified to judge the sensitivity and specificity of the applied laboratory tests in this study by comparing their results to existing or missing ocular changes in terms of ERU.

The highest level of agreement with the definite clinical diagnosis "ERU" was calculated for the ELISA technique and especially for the detection of specific IgA. It was also ascribed the highest sensitivity (86\%) and specificity $(100 \%)$ in assessing vitreous samples from clinically sick and healthy equine eyes. The most reliable way of evaluating laboratory tests, though, would be to assess them with samples from known carriers. In the diagnosis of leptospirosis, however, culture is time consuming and insensitive (Faine 1982) and therefore, seems inappropriate.

In the literature the MAT is often described as gold standard (Vinetz 1997) and newly developed ELISAs are often evaluated with the MAT being considered as the basing point. Bearing in mind that these two serological tests seemingly detect 
different antigen-antibody-systems (Adler et al. 1980, Adler et al. 1982, Ballard et al. 1984), doubts arise regarding the actual comparability of the two methods and the evaluation of the ELISA-technique on the basis of its agreement with the MAT results. Woodward and others (1997) also advised caution when interpreting ELISA results compared to MAT, as MAT itself would not deliver definitely correct results. Yan and others (1999) also criticized that the main source of errors in assessing the ELISA technique was a comparison of results from the MAT because the serological status, as determined by MAT, often would not mirror the actual infection status of the animal (cattle). Ribotta and others (2000) even assumed that the ELISA had a higher sensitivity than the MAT because it was able to detect both agglutinating and non-agglutinating antibodies. Thus, the actual specificity of the ELISA would be underestimated in an evaluation with the MAT set as gold standard. Further, a titre of 1:100 is often set as the cut-off in the MAT (OIE 2014). Considering a lower titre, e.g. 1:50, as being positive, a higher level of agreement might be achieved between MAT and ELISA. Numerous authors from both veterinary and human medicine have suggested that the ELISA had a higher sensitivity than the MAT in detecting anti-leptospiral antibodies (Adler et al. 1980, Brem et al. 1999b, Cumberland et al. 1999, Ribotta et al. 2000, Dutta and Christopher 2005, Loib/ 2009). Retrospective evaluation of case records on suspected leptospiral uveitis in horses with a negative result in the MAT revealed that $37 \%$ of the very same intraocular samples tested positive for leptospiral antibodies with ELISA (Loib/ 2009). Moreover, an increasing number of leptospiral infections in humans have been reported worldwide in both developing and developed nations. However, only a few laboratories possess the expertise and the equipment necessary for accomplishing a MAT in the diagnosis of leptospirosis. Therefore, the ELISA technique and the development of new indirect laboratory tests are of great importance for the routine diagnosis of leptospiral infections. This is proved by the increasing application of the ELISA both in veterinary and humane medicine.

In this study it was shown that the ELISA technique is appropriate to complement or even replace the MAT in detecting intraocular antibodies against Leptospira spp. in horses suffering from recurrent uveitis. This conclusion is especially valuable for aqueous humour analyses following diagnostic paracenteses in cases without definitive clinical signs in terms of ERU.

\section{Conflict of interest statement}

None of the authors of this paper has a financial or personal relationship with other people or organisations that could inappropriately influence or bias the content of the paper.

\section{References}

Adler B., Murphy A. M., S. A. Locarnini S. A., Faine S. (1980) Detection of specific anti-leptospiral immunoglobulins $M$ and $G$ in human serum by solid-phase enzyme-linked immunosorbent assay. J. Clin. Microbiol. 11, 452-457

Adler B., Cousins D. V., Faine S., Robertson G. M. (1982) The bovine $\lg M$ and $\lg G$ response to Leptospira interrogans serovar Hardjo as measured by enzyme-immunoassay. Vet. Microbiol. 7, 577-585
Baake E. I. A., V. Borstel M., Rohn K., Ohnesorge B. (2016) Detection of intraocular leptospiral DNA, antibodies and Leptospira spp. in horses with equine recurrent uveitis in different laboratories. Pferdeheilkunde 32, 346-356; DOI 10.21836/PEM20160407

Ballard S. A., Adler B., Millar B. D., Chappel R. J., Jones R. T., Faine S. (1984) The immunoglobulin response of swine following experimental infection with Leptospira interrogans serovar Pomona. Zbl. Bakt. Hyg. A 256, 510-517

Barnett K. C., Crispin S. M., Lavach J. D., Matthews A. G. (1995) Color Atlas and Text of Equine Ophthalmology. Mosby-Wolfe, Italy, pp 166

Baumgart A., Gerhards H. (2014) Besonderheiten der Tigerschecken-Uveitis und möglicher Cyclosporin A-Einsatz in deren Therapie in Deutschland. Pferdeheilkunde 30, 626-632; DOI 10.21836/PEM20140601

Bernard W. V. (1993) Leptospirosis. Vet. Clin. North Am. Equine Pract. 9, 435-444

Boswinkel M., Neyens I. J., Sloet van Oldruitenborgh-Oosterbaan M. M. (2006) Halicephalobus gingivalis infection in a 5 -year-old Tinker gelding. Tijdschr. Diergeneeskd. 131, 74-80

Brandes K., Wollanke B., Niedermaier G., Brem S., Gerhards H. (2007) Recurrent uveitis in horses: vitreal examination with ultrastructural detection of leptospires. J. Vet. Med. A 54, 270-275

Brem S., Gerhards H., Wollanke B., Meyer P., Kopp H. (1999a) 35 Leptospirenisolationen aus Glaskörpern von 32 Pferden mit rezidivierender Uveitis (ERU). Berl. Muench. Tieraerztl. Wschr. 112, 390-393

Brem S., Staak C., Schönberg A., Kopp H., Meyer P. (1999b) Beitrag zur Leptospirenserologie des Hundes. Vergleich von MAR- und ELISA-Ergebnissen. Tieraerztl. Umsch. 54, 83-87

Brem S., Wollanke B., Gerhards H. (2005) Individual communication.

Brihuega B., Samartino L., Auteri C., Venzano A., Caimi K. (2012) In vivo cell aggregations of a recent swine biofilm-forming isolate of Leptospira interrogans strain from Argentina. Rev. Argent. Microbiol. 44, 138-143

Burgess E. C., Gillette D., Pickett J. P. (1986) Arthritis and panuveitis as manifestations of Borrelia burgdorferi infection in a Wisconsin pony. J. Am. Vet. Med. Assoc. 189, 1340-1342

Cumberland P. C., Everard C. O. R., Levett P. N. (1999) Assessment of the efficacy of the $\lg M$ enzyme-linked immunosorbent assay (ELISA) and microscopic agglutination test (MAT) in the diagnosis of acute leptospirosis. Am. J. Trop. Med. Hyg. 61, 731-734

Deeg C. A. (2008) Ocular immunology in equine recurrent uveitis. Vet. Ophthalmol. 11 Suppl. 1, 61-65

Deeg C. A., Kaspers B., Gerhards H., Thurau S. R., Wollanke B., Wildner G. (2001) Immune responses to retinal autoantigens and peptides in equine recurrent uveitis. Invest. Ophthalmol. Vis. Sci. 42, 393-398

Deeg C. A., Thurau S. R., Gerhards H., Ehrenhofer M., Wildner G., Kaspers B. (2002) Uveitis in horses induced by interphotoreceptor retinoid-binding protein is similar to the spontaneous disease. Eur. J. Immunol. 32, 2598-2606

Deeg C. A., Martie E., Gaillard C., Kaspers B. (2004) Equine recurrent Uveitis is strongly associated with the MHC class I haplotype ELA-A9. Equine Vet. J. 36, 73-75

Deeg C. A., Pompetzki D., Raith A. J., Hauck S. M., Amann B., Suppmann S., Goebel T. W., Olazabal U., Gerhards H., Reese S., Stangassinger M., Kaspers B., Ueffing M. (2006) Identification and functional validation of novel autoantigens in equine uveitis. Mol. Cell Proteomics $5,1462-1470$

Dorrego Keiter E., Tóth J., Dikker L., Sielhorst J., Schusser G. F. (2016) Kultureller Nachweis von Leptospiren in Glaskörperflüssigkeit und Antikörpernachweis gegen Leptospiren in Glaskörperflüssigkeit und Serum von 225 Pferden mit equiner rezidivierender Uveitis (ERU). Berl. Muench. Tieraerztl. Wschr. 129, 209-215

Dorrego Keiter E., Tóth J., Dikker L., Sielhorst J., Schusser G. F. (2017) Langzeitergebnisse der Pars-Plana-Vitrektomie in Abhängigkeit vom Leptospiren-Antikörper-Nachweis im Glaskörper bei 118 Pferden mit Equiner Rezidivierender Uveitis (ERU). Pferdeheilkunde 33, 112-118; DOI 10.21836/PEM20170201 
Dutta T. K., Christopher M. (2005) Leptospirosis - an overview. J. Assoc. Physicians India 53, 545-551

Faber N. A., Crawford M., Le Febvre R. B., Buyukmihci N. C., Madigan J. E., Willits N. H. (2000) Detection of Leptospira spp. in the aqueous humor of horses with naturally acquired recurrent uveitis. J. Clin. Microbiol. 38, 2731-2733

Faine S. (1982) Guidelines for the control of leptospirosis. In WHO Offset Publication No. 67, WHO, Geneva

Faine S., Adler B., Bolin C., Perolat P. (2000) Leptospira and Leptospirosis. Medi Sci, Melbourne, Australia, (2. Ed.)

Gerhards H., Wollanke B., Brem S. (1999) Vitrectomy as a diagnostic and therapeutic approach for equine recurrent uveitis (ERU). In Proceedings 45th Ann. Conv. AAEP, Albuquerque, p. 89-93

Gerhards H., Wollanke B. (2001) Uveitis bei Pferden - Diagnose und Therapie. Pferdeheilkunde 17, 319-329; DOI 10.21836/ PEM20010402

Gerhards H., Wollanke B. (2005) Surgical treatment of equine recurrent uveitis: Trans-pars-plana vitrectomy in horses. In: Gilger B. C. (ed.) In: Equine Ophthalmology, 1 st edition. Elsevier Saunders, p. 314-319

Gerhards H., Wollanke B. (2006) Equine Rezidivierende Uveitis. In: Dietz O. and Huskamp B. (Eds.) In: Handbuch Pferdepraxis. Stuttgart, Enke Verlag, p. 775-786

Gesell S. (2004) Gibt es eine asymptomatische intraokulare Leptospireninfektion beim Pferd? Diss. Med. Vet. München

Gesell S., Wollanke B., Gerhards H., Brem S., Meyer P., H. Kopp H. (2005) Vergleich intraokularer Antikörpertiter gegen Leptospiren in Kammerwasser- und Glaskörperproben von Pferden mit equiner rezidivierender Uveitis (ERU). Tagungsband der 13. Jahrestagung der DVG-Fachgruppe "Innere Medizin und Klinische Labordiagnostik" in München, 5.-6.2.2005

Gesell S., Wollanke B., Brem S., Gerhards H. (2006) Vergleich der Antikörpertiter gegen Leptospiren in Kammerwasser- und Glaskörperproben bei Pferden mit rezidivierender Uveitis. Poster, 19. DVG-Fachtagung Pferdekrankheiten, Hannover, 2006

Gilger B. C., Malok E., Cutter K. V., Stewart T., Horohov D. W., Allen J. B. (1999) Characterisation of T-lymphocytes in the anterior uvea of eyes with chronic equine recurrent uveitis. Vet. Immunol. Immunopathol. 71, 17-28

Gilger B. C., Salmon J. H., Yi N. Y., Barden C. A., Chandler H. L., Wendt J. A, Colitz C. M. H. (2008) Role of bacteria in the pathogenesis of recurrent uveitis in horses from the southeastern United States. Am. J. Vet. Res. 69, 1329-1335

Gum G. G. (1991) Physiology in the eye. In: Gelatt K. N. (Ed.): Textbook of veterinary ophthalmology, 2. ed., Lea \& Felbinger, Philadelpia, p.124-161

Halliwell R. E., Brim T. A., Hines M. T., Wolf D., White F. H. (1985b) Studies on equine recurrent uveitis. II: The role of infection with Leptospira interrogans serovar Pomona. Curr. Eye Res. 4, 1033 1039

Hahn C. N., Mayhew I. G., Whitwell K. E., Smith K. C., Carey D., Carter S. d., Read R. A. (1996) A possible case of Lyme borreliosis in a horse of the UK. Equine Vet. J. 28, 84-88

Hanson L. E. (1973) Immunologic problems in bovine leptospirosis. J. Am. Vet. Med. Assoc. 163, 919-921

Hartskeerl R. A., Goris M. G., Brem S., Meyer P., Kopp H., Gerhards H., Wollanke B. (2004) Classification of leptospira from the eyes of horses suffering from recurrent uveitis. J. Vet. Med. B Infect. Dis. Vet. Public Health 51, 110-115

Isaza R., Schiller C. A., Stover J., Smith P. J., Greiner E. C. (2000) Halicephalobus gingivalis (Nematoda) infection in a Grevy's zebra (Equus grevyi). J. Zoo Wildl. Med. 31, 77-81

Kalsow C. M., Dwyer A. E. (1997) Role of leptospiral infection in equine recurrent uveitis. In United States Animal Health Association Proceedings

Kettner H. (1997) Untersuchungen zur klinischen Epizootiologie und Diagnostik der Leptospireninfektion beim Pferd. Diss. Med. Vet. Munich

Kinde H., Mathews M., Ash L., St. Leger J. (2000) Halicephalobus gingivalis $(\mathrm{H}$. deletrix) infection in two horses in southern California. J. Vet. Diagn. Invest. 12,162-165
Kulbrock M., von Borstel M., Rohn K., Distl O., Ohnesorge B. (2013) Studie zu Häufigkeit und Schweregrad der Equinen Rezidivierenden Uveitis bei Warmblütern. Pferdeheilkunde 29, 27-36; DOI: 10.21836/PEM20130105

Kumar K. V., Lall C., Rai R. V., Vedhagiri K., Vijayachari P. (2015) Coexistence and survival of pathogenic leptospires by formation of biofilm with Azospirillum. FEMS Microbiol. Ecol. 91, pii: fiv051, DOI: 10.1093/femsec/fiv051

Loib/ J. (2009) Immunologische und mikrobiologische Untersuchungen zur intraokular persistierenden Leptospireninfektion bei Pferden mit rezidivierender Uveitis. Diss. Med. Vet. München

Malalana F.,Blundell R. J., Pinchbeck G. L., Mcgowan C. M. (2017) The role of Leptospira spp. in horses affected with recurrent uveitis in the UK. Equine Vet. J. 49, 706-709 (DOI 10.1111/evj.12683)

Morter R. L., Williams R. D., Bolte H., Freeman M. J. (1969) Equine leptospirosis. J. Am. Vet. Med. Assoc. 155, 436-442

OIE (2014) Leptospirosis. In: OIE Terrestrial Manual, p. 251-64; www.oie.int

Niedermaier G., Wollanke B., Hoffmann R., Brem S., Gerhards H. (2006) Detection of leptospira in the vitreous body of horses without ocular diseases and of horses with equine recurrent uveitis (ERU) using transmission-electron microscopy (Article in German: Darstellung von Leptospiren im Glaskörper augengesunder und an ERU erkrankter Pferde mittels Transmissions-Elektronenmikroskopie). Dtsch. Tieraerztl. Wschr. 113, 418-422

Parma A. E., Fernandez A., Santisteban C., Bowden R., Cerone S. (1987) Tears and aqueous humor from horses inoculated with Leptospira contain antibodies which bind to cornea. Vet. Immunol. Immunopathol. 14, 181-185

Popp M., Gerhards H., Wollanke B. (2013) Enrofloxacinkonzentrationen im Glaskörper und im Serum an equiner rezidivierender Uveitis (ERU) erkrankter Pferde nach wiederholter intravenöser Verabreichung. Pferdeheilkunde 29, 574-580; DOI 10.21836/PEM 20130501

Priest H. L., Irby N. L., Schlafer D. H., Divers T. J., Wagner B., Glaser A. L., Chang Y.-F., Smith M. C. (2012) Diagnosis of Borrelia-associated uveitis in two horses. Vet. Ophthalmol. 15, 398-405

Priya C. G., Bhavani K., Rathinam S. R., Muthukkaruppan V. R. (2003) Identification and evaluation of LPS antigen for serodiagnosis of uveitis associated with leptospirosis. J. Med. Microbiol. $52,667-673$

Rames, D. S., D. K. Miller, R. Barthel, T. M. Craig, J. Dziezyc, R. G. Helman und R. Mealey (1995) Ocular Halicephalobus (syn. Micronema) deletrix in a horse. Vet. Pathol. 32, 540-542

Ribotta M. J., Higgins R., Gottschalk M., Lallier R. (2000) Development of an indirect enzyme-linked immunosorbent assay for the detection of leptospiral antibodies in dogs. Can. J. Vet. Res. 64, 32-37

Ristow P., Bourhy P., Kerneis S., Schmitt C., Prevost M. - C., Lilenbaum W., Picardeau M. (2008) Biofilm formation by saprophytic and pathogenic leptospires. Microbiology 154, 1309-1317; DOI 10.1099/mic.0.2007/014746-0

Roczek A. H. (2008) Entwicklung einer quantitativen PCR zum Nachweis von DNA pathogener Leptospiren in Glaskörper- und Kammerwasserproben von Pferden. Diss. Med. Vet. München

Roczek A., Forster C., Raschel H., Hoermannsdorfer S., Bogner K.H., Hafner-Marx A., Lepper H., Dobler G., Buettner M., Sing A. (2008) Severe course of rat bite-associated Weil's disease in a patient diagnosed with a new Leptospira-specific real-time quantitative LUX-PCR. J. Med. Microbiol. 57, 658-663

Roth T., Brandes K., Gerhards H., Giving E., Wollanke B. (2014) Histologische Untersuchungen des Glaskörpers bei Pferden mit equiner rezidivierender Uveitis. Pferdeheilkunde 30, 512-520; DOI 10.21836/PEM20140501

Sandmeyer L. S., Baver B. S., Feng C. X., Grahn B. H. (2017) Equine recurrent uveitis in western Canadian prairie provinces: $A$ retrospective study (2002-2015). Can. Vet. J. 58, 717-722

Schinagl C. (2017) Pars-Plana-Vitrektomie bei Equiner Rezidivierender Uveitis - Langzeitergebnisse zu Rezidivfreiheit, Sehfähigkeit und Bulbuserhalt bei 654 Augen von 549 Pferden. Diss. Med. Vet. München 
Szemes P. A., Gerhards H. (2000) Untersuchungen zur Prävalenz der equinen rezidivierenden Uveitis im Großraum Köln-Bonn. Prakt. Tierarzt 81, 408-420

Thibeaux R., Soupé-Gilbert M. E., Picardeau M., Goarant C. (2017) Biofilms of pathogenic leptospira: a compromise between virulence and environmental survival? Proceedings 10th ILS Conference, Palmerston North, New Zealand, p. 85

Thurau S. (2003) Praktische Hinweise zur Gewinnung und erfolgreichen Aufbereitung von Vorderkammerpunktat und Vitrektomiematerial. Ophthalmologe 100, 802-807

Tizard I. R. (2004) Veterinary immunology. An introduction. In W. B. Saunders Company, 2004

Tömördy E., Hässig M., Spiess B. M. (2010) The outcome of pars plana vitrectomy in horses with equine recurrent uveitis with regard to the presence or absence of intravitreal antibodies against various serovars of Leptospira interrogans. Pferdeheilkunde 26, 251-254; DOI 10.21836/PEM20100222

Verma A., Artiushin S., Matsunaga J., Haake D. A., Timoney J. F. (2005) LruA and LruB, novel lipoproteins of pathogenic Leptospira interrogans associated with equine recurrent Uveitis. Infect. Immun. 73, 7259-7266

Vinetz J. M. (1997) Leptospirosis. Curr. Opinion Inf. Dis. 10, $357-$ 361

von Borstel M., von Oppen T., Glitz F., Frühauf B., Deegen E., Boevé M. H., Ohnesorge B. (2005) Langzeitergebnisse der Pars plana Vitrektomie (double port) bei Equiner Rezidivierender Uveitis. Pferdeheilkunde 21, 13-18; DOI 10.21836/PEM20050102

von Borstel M., Oey L., Strutzberg-Minder K., Boevé M. H., Ohnesorge B. (2010) Direkter und indirekter Nachweis von Leptospiren aus Glaskörperproben von Pferden mit ERU. Pferdeheilkunde, 26, 219-225; DOI 10.21836/PEM20100217

Wagner B., Brandt K., Sheoran A., Holmes M. A., Deegen E., Leibold W. (1997) Nachweis von Immunglobulinisotypen im Glaskörper als Beitrag zur Ätiologie der equinen rezidivierenden Uveitis. Dtsch. Tieraerztl. Wschr. 104, 461-470

Wagner B., Glaser A., Bartol J., Mahar O., Johnson A., Divers T. (2011) A new sensitive Lyme Multiplex Assay to confirm neuroborreliosis in horses: a case report. AAEP Proc. 57, 70-75

Wiehen L. E. (2012) Retrospektive Analyse zum Vorkommen der Equinen rezidivierenden Uveitis - unter Berücksichtigung der Leptospireninfektion - an der LMU München von 01/2005 bis 06/2010. Diss. Med. Vet. München

Williams R. D. (1968) The Presence and Duration of Persistence of Leptospira pomona in Equine Ocular Tissues Following Experimentally Induced Systemic Infection. Master of Science Thesis, Purdue University

Winterberg A., Gerhards H. (1997) Langzeitergebnisse der Pars-plana-Vitrektomie bei equiner rezidivierender Uveitis. Pferdeheilkunde 13, 377-383; DOI 10.21836/PEM19970409

Witmer R. H. (1954) Periodic ophthalmia in horses. Am. J. Ophthalmol. 37, 243-253

Wollanke B. (1995) Untersuchungen zur Ätiologie der equine rezidivierenden Uveitis (ERU). Diss. Med. Vet. München

Wollanke B. (2002) Die equine rezidivierende Uveitis. Habil. Med. Vet. München
Wollanke B., Gerhards H., Brem S., Kopp H., Meyer P. (1998a) Intraokulare und Serumantikörpertiter gegen Leptospiren bei 150 wegen equiner rezidivierender Uveitis (ERU) vitrektomierten Pferden. Berl. Muench. Tieraerztl. Wschr. 111, 134-139

Wollanke B., Gerhards H., Brem S., Gothe R., Wolf E., Herzog S., Kopp P., Meyer P. (1998b) Studies on vitreous and serum samples from horses with equine recurrent uveitis (ERU): The role of Leptospira, Borrelia burgdorferi, Borna disease virus and Toxoplasma in the etiology of ERU. Tagungsbericht des 29. ACVO-Meetings, Seattle, 31

Wollanke B., Gerhards H., Brem S., Gothe R., Herzog S., Kopp H., Meyer P., Wolf E. (1998c) Untersuchungen von bei Vitrektomien gewonnenem Glaskörpermaterial unter besonderer Berücksichtigung der Beteiligung verschiedener Erreger an der Ätiologie der equinen rezidivierenden Uveitis (ERU). Tagungsband der 8. FVOTagung in Erfurt, 27.-28.6.1998

Wollanke B., Gerhards H., Brem S., Kopp H., Meyer P. (1999) Cultural confirmation of the leptospiral etiology of equine recurrent uveitis. 6. WEVA-Congress (World Equine Veterinary Congress), Paris, Abstract in: J. Equine Vet. Sci. 19, 564-565

Wollanke B., H. Gerhards, Schäffer E. (2000a): Keratouveitis und Makrohaematurie bei einer Infektion mit Micronema deletrix bei einem Pferd. Pferdeheilkunde 16, 23-29; DOI 10.21836/PEM 20000102

Wollanke B., Gerhards H., Brem S., Wolf E., Kopp H., Meyer P. (2000b) Zur Leptospirenätiologie der equinen rezidivierenden Uveitis (ERU): Ergebnisse der Untersuchungen von Serum- und Glaskörperproben. Tieraerztl. Prax. 28 G, 153-158

Wollanke B., Gerhards H. (2001a) Confirmation of the leptospiral aetiology of ERU with vitreous material obtained by vitrectomy. Tagungsbericht des 40. BEVA-Kongresses (British Equine Veterinary Association) in Harrogate, p. 171-172

Wollanke B., Rohrbach B. W., Gerhards H. (2001 b) Serum and vitreous humor antibody titers in and isolation of Leptospira interrogans from horses with recurrent uveitis. J. Am. Vet. Med. Assoc. $219,795-800$

Wollanke B., Gerhards H., Brem S., Meyer P., Kopp H. (2004 a) Ätiologie der equinen rezidivierenden Uveitis (ERU): Autoimmunkrankheit oder intraokulare Leptospireninfektion? Pferdeheilkunde 20, 327-340; DOI 10.21836/PEM20040403

Wollanke B, Brem S, Meyer P, Forbig T, GrassI P, Gerhards H, Kopp H. (2004 b) Prophylaxe der equinen rezidivierenden Uveitis (ERU): Erste Erfahrungen mit einem Leptospiren-Impfstoff bei Pferden. Pferdeheilkunde 20, 447-454; DOI 10.21836/PEM20040506

Wollanke B., Gerhards H., Kaufmann S. (2017 a) Untersuchungen zur Beteiligung von Borrelien an der Ätiologie der equinen rezidivierenden Uveitis (ERU). Pferdeheilkunde 33, 447-451; DOI 10.21836/PEM20170504

Woodward M. J., Swallow C., Kitching A., Dalley C., Sayers A. R. (1997) Leptospira hardjo serodiagnosis: a comparison of MAT, ELISA and immunocomb. Vet. Rec. 141, 603-604

Yan K. T., Ellis W. A., Mackie D. P., Taylor M. J., McDowell S. W., Montgomery J. M. (1999) Development of an ELISA to detect antibodies to a protective lipopolysaccharide fraction of Leptospira borgpetersenii serovar Hardjo in cattle. Vet. Microbiol. 69, 173-187 